\section{ON THE ORIGIN AND METAMORPHOSES OF INSECTS*}

\section{III.}

THE INFLUENCE OF EXTERNAL CONDITIONS ON THE FORM AND STRUCTURE OF LARVF

$T \mathrm{HE}$ facts recapitulated very briefly in the preceding chapters show, that the forms of insect larvæ depend greatly on the group to which they belong. Thus the same tree may harbour larve of Diptera, Hymenoptera, Coleoptera, and Lepidoptera; each presenting the form typical of the group to which it belongs.
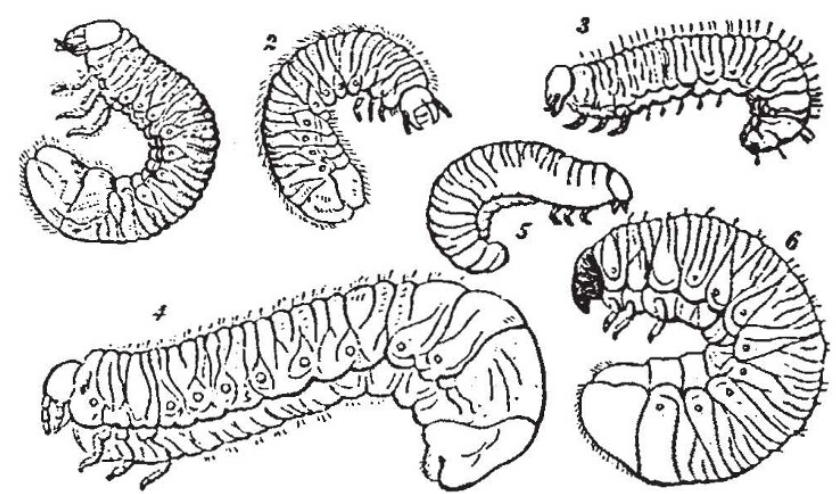

FıG. x. Larva of the Cockchafer (Melolontha). (Westwood. Int. to the Modern Classification of Insects, v. I., p. y94.) 2, Larva of Cetonia, 3, Larva of Trox 4, Larya of Oryctes. 5, Larva of Aphodius. (Chapuis and Candeze, Mem. Soc. Roy. Liege, 1853 . 6, Larva of Lucanus. (Packard, "Guide to the Study of Insects," Fig. 403).

If, again, we take a group, such, for instance, as the Lamellicorn beetles, we shall find larva extremely similar in form, yet very different in habits. Those for instance of the common cockchafer (Fig. I) feed on the roots of grass, those of Cetonia aurata (Fig. 2) are found in ants' nests; the larva of the genus Trox (Fig. 3) on dry animal substances; of Oryctes (Fig. 4) in tan-pits : of Aphodius (Fig. 5) in dung; of Lucanus (the stag-bectle, Fig. 6) in wood.

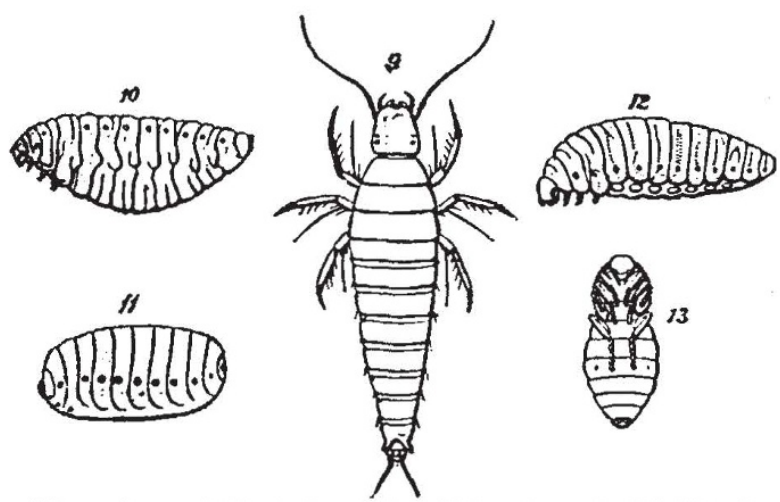

Fic. 9. Larva of Sitaris humeralis. (Fabre, Ann. d. Sci. Nat. Ser. 4, vol. vii.) 10 , Larva of Sitaris humeralis. in the second stage. humeralis, in the fourth stage. $x_{3}$, Pupa of Sitaris.

In the present chapter it will be my object to show that the form of the larva depends also very much on its mode of life. Thus, those larvæ which are internal parasites, whether in animals or plants, belong to the vermiform state; and the same is the case with those which live in cells, and depend on their parents for food. On the other hand, larva which burrow in * Continued from vol. vii. p. $4^{89}$. wood have strong jaws and generally somewhat weak thoracic legs; those which feed on leaves have the thoracic legs more developed, but less so than the carnivorous species. Now, the Hymenoptera, as a general rule, belong to the first category: the larvae of the Ichneumons, \&c., which live in animals,-those of the Cynipida, which inhabit galls, - and those of ants, bees, wasps, \&c., which are fed by their parents, are all fleshy, apodal grubs. On the other hand, the larvæ of Sirex, which are wood-burrowers, quit the type which is common to the majority of the order, and remain in the egg until they have developed small thoracic legs. Again, the larva of the Tenthredinide, which feed upon leaves, closely
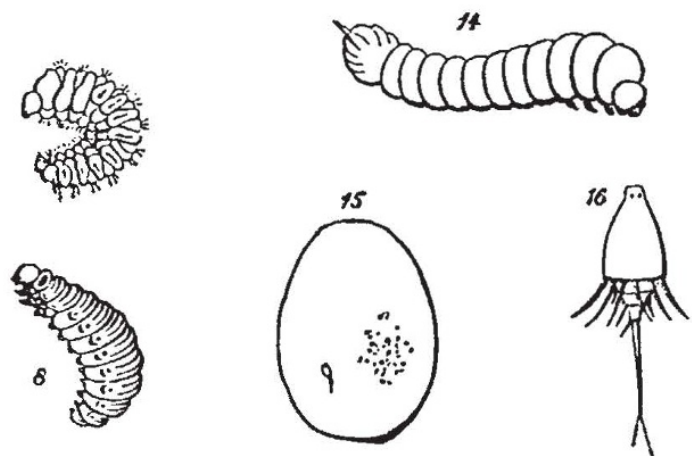

Fic. 7, Lirva of Brachytarsus (Ratzebu:g, Forst. Insectea). 8. Larva of Cri.xceris (Westwood, l.c.) I4. Larva of Sirex (IVestwood l.c) 15 . $\mathrm{E}_{\text {gg }}$ of Rhynchites, showing the parasitic larva in the interior. 16, the parasitic larva nore magnified.

resemble the caterpillars of Lepidoptera, even to the presence of abdominal prolegs. There is, however, some little variety in this respect, some species having eleven pairs, some ten, some nine, while the genus Lyda. has only the three thoracic pairs.

Again, the larva of beatles are generally active, hexapod, and more or less flattened: but on the other hand with those specics which live inside vegetable tissues, such as the weevils, they are apod fleshy grubs, like those of Hymenoptera. Pl. 2, Fig. 6, represents the larva of

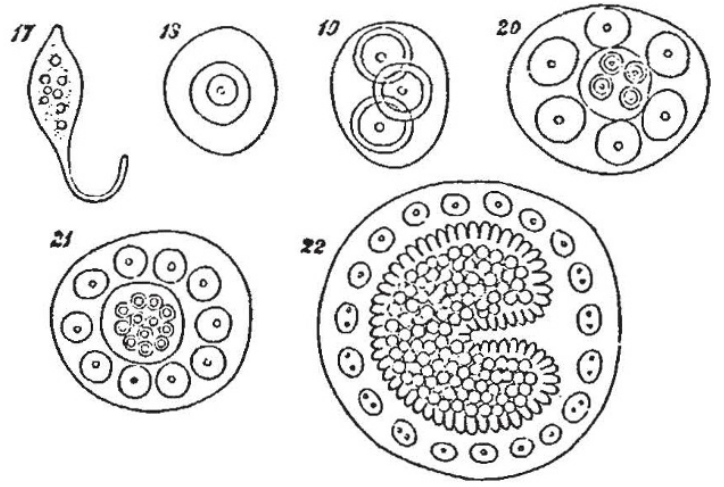

Fig. 37, Egg of Platygaster (after Ganin). 18, Egg of Platygaster showing the central cell. 29, Egg of Platygaster after the divssion of the central wall 20, Egg of Platygaster more advanced. $2 x$, Egg of Platygaster more advanced. 22, Egg of Platygaster showing the rudiment of the embryo.

the nut-weevil, Balaninus (Pl. I, Fig. 6), and it will be seen that it closely resembles $\mathrm{Pl} .2$, Fig. 5 , which represents that of a fly (Anthrax), PI. I, Fig. 5, and Pl. 2, Figs. 7, 8 , and 9, which represent respectively those of a Cynips or gall-fly (Pl. I, Fig. 7), an ant (PI. 1, Fig. 8), and wasp (P1. I, Fig. 9). Nor is this the only group of Coleoptera which affords us examples of this fact. Thus in the genus Scolytus (PL. I, Fig. 4), the larvx (Pl. 2, Fig. 4), 
which, as already mentioned, feed on the bark of the elm. closely resemble those just described, as also do those of Brachytarsus (Fig. 7). On the other hand the larva of certain beetles feed on leaves, like the caterpillars of Lepidoptera ; thus the larva of Crioceris Asparagi (Fig. 8), which, as its name denotes, feeds on the asparagus, closely resembles that of certain Lepidoptera, as for instance of Thecla spini. A striking illustration of this is afforded by the genus Sitaris (PI. 3, Fig. 4), a small beetle allied to Cantharis, the blister-fly, and Meloe, the oil-beetle. The habits of this species have been very carefully investigated by M. Fabre.*

The genus Sitaris is parasitic on Anthophora, in the galleries in which it lays its eggs. These are hatched at the end of September or beginning of October; and M. Fabre not unnaturally expected that the young larva, which, as already mentioned, are active little

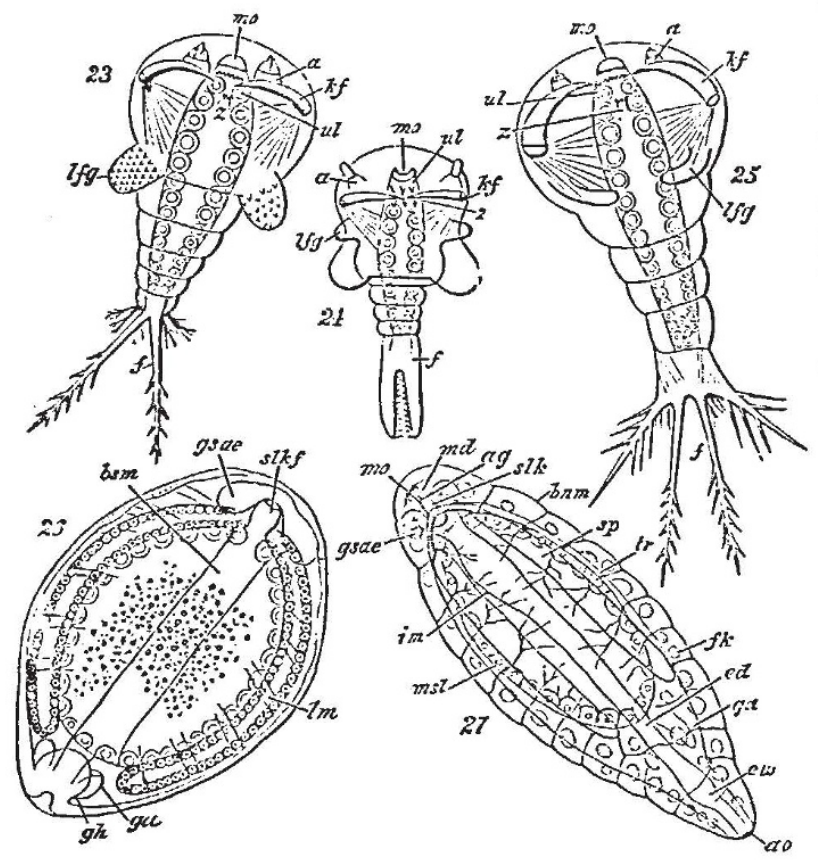

Fig. 23, Larva of Platygaster (after Ganin)-mo, mouth; $a$, antenna; $k f$, hcoked feet ; $r$, toothed process; $l f g$, lateral prccess; $f$, branches of the tail. 24 , Larva of another species of Platygaster. I heletters indicate the same parts as in the preceding figure. 25, Larva of a third species of Platygaster. The letters indicate the same parts as in the preceding figures. 66 , Larva of Platygaster in the secord stage $-m 0$, mouth; s lkf, cesofhagus; $g s a e$, supra oesophagal ganglion: $l m$, muscles; bs $m$, nervous system; $g$ a $g$, rudiments of the reproductive glands. 27, Larva of Platygaster in the third stage-me, mouth; $m d$, mandibles; $g s a e$, supra-csorhagal ganglion; s $2 k$, cesophagus; $a g$, ducts of the salivary glands ; $b n$, ventral nervous system i s $p$, salivary glands; $7 n s i$, stcmach; $i$, imaginal discs ; $t r$, trachex ; $f k$, fatty porticn of intestine; $a 0$, pesterior opening.

creatures with six serviceable legs (Fig. 9), would at once eat their way into the cells of the Anthophora. No such thing : till the month of April following they remain without leaving their birth-place, and consequently without food; nor do they in this long time change either in form or size. M. Fabre ascertained this, not only by examining the burrows of the Anthophoras, but also by direct observation of some young larva kept in captivity. In April, however, his specimens at last threw off their long lethargy, and hurried anxiously about their prisons. Naturally inferring that they were in search of food, M. Fabre supposed that this would consist cither of the larva or pupæe of the Anthophora, or of the honey with which it stores its cell. All three were tried without *Ann. da5. Sc. Nat. V. vii. T, 4. See also Natural History Review, April r862, success. The two first were neglected, and when placed on the latter the larva hurried away, or perished in the attempt, being evidently unable to deal with the sticky substance. M. Fabre was in despair : Jamais experience," he says, "n'a éprouvé pareille déconfiture. Larves, nymphes, cellules, miel, je vous ai tous offert; que voulez-vous donc, bestioles maudites?" The first ray of light came to him from our countryman, Newport, who ascertained that a small parasite found by Leon Dufour on one of the wild bees, and named by him Triungulinus, was, in fact, the larva of the Meloe. The larva of Sitaris much resembled Dufour's Triungulinus; and acting on this hint, M. Fabre examined many specimens of Anthophora, and at last found on them the larvx of his Sitaris. The males of Anthophora emerge from the pupie before the females, and he ascertained that as they come out of their galleries, the little larvar fasten upon them. Not, however, for long: their instinct teaches them that they are not yet in the straight path of development ; and, watching their opportunity, they pass from the male to the female bee. Guided by these indications, MI. Fabre examined several cells of Anthophora: in some, the egg of the Anthophora floated by itself on the surface of the honey ; in others, on the egg, as on a raft, sat the still more minute larva of the Sitaris. The mystery was solved. At the moment when the egg is laid, the Sitarislarva springs upon it. Even while the poor mother is carefully fastening up her cell, her mortal enemy is beginning to devour her offspring. For the egg of the Anthophora serves not only as a raft, but as a repast. The honey, which is enough for either, would be too little for both; and the Sitaris, therefore, in its first meal, relieves itself from its only rival. After eight days the egg is consumed, and on the empty shell the Sitaris undergoes its first transformation, and makes its appearance in a very different form as shown in Fig. 10.

The honey which was fatal before is now necessary; the activity which before was necessary, is now useless; consequently, with the change of skin the active, slim larva changes into a white, fleshy grub, so organised as to float on the surface of the honey, with the mouth below, and the spiracles above the surface; "grâce it l'embonpoint du ventre," says MI. Fabre, "la larve est iे l'abri de l'asphyxie." In this state it remains till the honey is consumed; then the animal contracts, and detaches itself from its skin, within which the other transformations take place. In the next stage, which $M$. Fabre calls the pseudo-chrysalis (Fig. II), the larva has a solid corneous envelope and an oval shape, and in its colour, consistency, and immobility reminds one of a Dipterous pupa. The time passed in that condition varies much. When it has elapsed, the animal moults again, and again changes its form, and assumes that shown in Fig. 12; after this it becomes a pupa (Fig. 13) without any remarkable peculiarities; and finally, after these wonderful changes and adventures, in the month of August the perfect Sitaris (PI. 3, Fig. 4) makes its appearance.

d. On the other hand, there are cases in which larva iverge remarkably from the ordinary type of the group to which they belong, without, as it seems in our present imperfect state of information, any sufficient reason.

Thus the ordinary type of Hymenopterous larva, as we have already seen, is a fleshy apod grub; replaced however in the leaf-eating and wood-boring groups, Tenthredinidæe and Sirecida (Fig. 14) by caterpillars, more or less closely resembling those of Lepidoptera. There is, however, a group of minute Hymenoptera, the larva of which reside within the eggs or larve of other insects. It is difficult to understand why these larva should differ from those of Ichneumons, but as will be seen by the accompanying figures, they assume very remarkable and grotesque forms. The first of these curious larvæ was observed by De Filippi,

\footnotetext{
* Ann, and Mag.lof Nat. His, 1852.
} 
who had collected some of the transparent ova of Rhynchites betuleti and to his great surprise found more than half of them attacked by a small parasite, which proved to be the larva of a minute Hymenopterous insect belonging to the Pteromalide. Fig. 15 shows the egg of Rhynchites, with the parasitic larva, which is represented on a larger scale in Fig, 16. Recently, however, this group has been more completely studied by M. Ganin,* who thus describes the development of Platygaster. The egg, as in other allied hymenopterous families, for instance in Cynips, is elongated and club-shaped (Fig. 17). After a while a large nucleated cell appears in the centre (Fig. 18) this is a new formation not derived from the germinil vesicle. This nucleated cell divides (Fig. 19) and subdivides. The outermost cells continue the same process, thus forming an outer investing layer. The central one, on the contrary, enlarges considerably, and develops within itself a number of daughter cells (Figs. 20 and 2 I), which gradually form themselves into a mulberry-like mass, thus giving rise to the embryo (Fig. 22).

Ganin met with these larve in thosc of a small gnat, Cecidomyia. Sometimes as many as fifteen parasites occured in one host, but as a rule only one attained maturity. The three species of Platygaster differed considerably in form, as shown in the threc following Figs. (23-25). They creep about in the egr by means of the strong hooked feet, $k f$, somewhat aided by movements of the tail. They possess a mouth, stomach, and muscles, but the nervous, vascular, and respiratory systems do not make their appearance until later. After some time the larva changes its skin and assunies the form represented in Fig. 26. In this moult the last abdominal scgment of the first larva is entirely thrown off : not merely the outer skin as in the case of the other segments, but also the hypodermis and the muscles. This larva, as will be seen by the figure, is in the form of a barrel or egg, and $.870 \mathrm{~mm}$. in length, the external appendages having disappeared, and the segments being indicated only by the arrangement of the muscles; $s l k f$ is the cesophagus leading into a wide stomach which occupies nearly the whole body, $s g s a e$ is the rudiment of the supracesophagal ganglia, $b s u$ the ventra nervous cords. The ventral nervous mass has the form of a broad band, with straicht sides; it consists of embryonal cells, and remains in this undeveloped condition, during the whole larval state.

At the next moult the larva enters its third state, which, howcver, as far as the external form (Fig. 27) is concerned, differs from the second only in being somewhat more elongated. The internal organs, however, are much more complex and complete. The trachere have made their appearance, and the mouth is provided with a pair of mandibles. From this point the metamorphoses of Platygaster do not appear to differ materially from those of other Hymenoptera.

An allied genus, Polynema, has also very curious larva. The perfect insect is aquatic in its habits, swimming by means of its wings ; flying, if we may say so, under water. It lays its eggs inside those of Dragon flies; and the Iarva, as shown in Figr. 28, leaves the egg in the form of a bottled-shaped mass of undifferentiated embryonal celis, covered by a thin cuticle, but without any trace of further organisation. Protected $b$, the egg shell of the Dragon fly, the young Polynema is early able to dispense with its own; and bathed in the nourishing fluid of the Dragon fly's egg, it imbibes nourishinent through its whole surface, and increases rapidly in size. The digestive canal gradually makes its appearance, the cellular mass forms beneath the original cuticle a new skin, distinctly divided into segments, and provided with certain appendages. After a while the old cuticle is thrown off, and the larva gradually assumes the form shown in Fig. 29. asch are the antennal discs, or

$$
\text { * Zeits. f. Wiss. Zool., } 28 \mathrm{cg} \text {. }
$$

rudiments of the antennx, $f l s c h$ of the wings, $b s c h$ of the legs, $v f g$ are lateral projections, $g s c h$ of the ovipositor, \&c., $f k$ is the fatty tissue. The subsequent metamorphoses of Polynema offer no special peculiarities.

From these facts-and, if necessary, many more of the same nature might have been brought forward-it scems to me evident that while the form of any given larva depends to a certain extent on the group of insects to which it belongs, it is also greatly influenced by the external conditions to which the animal is subjected; that it is a function of the life which the larva leads and of the group to which it belongs.

The larva of insects are generally regarded as being nothing more than immature states-as stages in the development of the egg into the imago; and this might more especially appear to be the case with those insects in which the larva offer a general resemblance in form and structure (excepting of course so far as relates to the wings) to the perfect insects. Nevertheless we see that this would be a very incomplete view of the case The larva and pupa undergo changes which have no relation to the form which they will ultimately assume. With a gencral tendency, as regards size and the production of wings, to this goal, there are combined other changes bearing reference only to their existing wants and condition. Nor is there in this, I think, anything which need

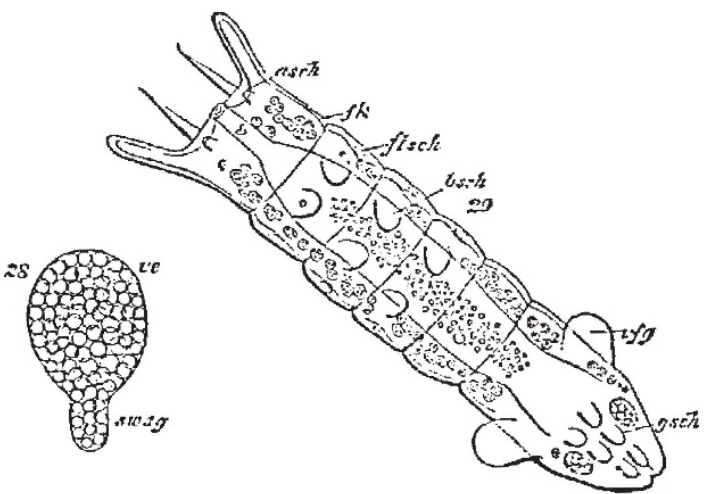

Fig. 28, Embryo of Polynema (afiet Gania). 39, Larva of Polynema, asch, rudiments of the antenys; $f l s c h$ of the wings; $b s c h$ of tho eggs; $p f g$.
$f k$, tatty tissue.

surprise us. External circunstances act on the insect in its preparatory states, as well as in its perfect condition. Those who belicve that animais are susceptible of great, though gradual, change through the influence of external conditions, whether acting, as MIr. Durwin has suggested, through natural selection, or in any other manner, will see no reason why these changes should be confined to the mature animal. And it is evident that creatures which, like the majority of insects, live during different parts of their existence in very different circumstances, may undergo considerable changes in their larval organisation, in consequence of forces acting on their larval condition; not, indeed, without affectins, but certainly without affecting to any corresponding extent, their ult:mate form.

I conclude, therefore, that the form of the larva in insects, whenever it departs from the ori ginal vermiformor the later Campodea-type, depend 3 in great measure on the conditions in which it lives. The external forces acting upon it are different from those which affect the mature form; and thus change; are produced in the young, which have reference to its immediate wants, rather than to its final form.

And, lastly, as a consequence, that metamorphoses may be divided into two kinds, developmental and adaptional. 